\title{
The Mode and Countermeasure of Social Power Participating in Social Assistance*
}

\author{
Yixi Liu \\ Wenzhou Vocational College of Science and Technology \\ Wenzhou, China 325006
}

\begin{abstract}
This article unifies the targeted poverty alleviation mode of "cooperation between village enterprise" under the background of grass-roots party construction to innovates and practices the Thai merchants, companies, collectives and farmers "four-in-one" poverty alleviation cooperation mode where new social power participate in social assistance under the mode of "party construction plus", and summarizes and refines the effect and characteristics of the reform in this village in order to provide some practical basis and experience and inspiration for the similar areas.
\end{abstract}

Keywords-social forces; social assistance; poverty alleviation; countermeasure

\section{INTRODUCTION}

The Fifth Plenary Session of the 18th Central Committee of the CPC, proceeding from the goal of building a well-off society in an all-round way, makes it clear that by 2020 , the poor in rural areas will get rid of poverty, the poor counties will be taken off their hats, and the overall regional poverty will be solved. [1] The 2015 Central Conference on Poverty Alleviation and Development pointed out that eliminating poverty, improving people's livelihood, and gradually realizing common prosperity are the essential requirements of socialism as well as the important mission of our party. The central collective leadership with $\mathrm{Xi}$ Jinping as the general secretary proposes "precision poverty alleviation", which needs us to adhere to targeted poverty alleviation, targeted poverty relief, and focus on improving the effectiveness of poverty eradication. The key is to find the right way to build a good system and mechanism, give practical solution in the precise implementation of policy, make effort in the precise promotion, and achieve actual effect in the precise landing, to solve the problem of "who to help", and "how to help". [2] We not only need to consider the problem and find a way out from the "issues of agriculture, farmer and rural area" itself, but also should jump out of the "issues of agriculture, farmer and rural area" to consider the problem and study the countermeasures from the overall situation of economic and social development; we should not only vigorously tap the potential of internal income increase, but also seek external ways to increase income; we should not only focus on development and

*Fund Support: Zhejiang Science and Technology Department General Soft Science Research Project "Research on Social Power Participation in Social Assistance under the Guidance of the Government" (No. 2016C35SA300003) cultivate new growth points, but also quicken the pace of reform and resolve deep-seated contradictions and problems. Xue Ne village in San Kui town speeds up the formation of the vanguard of the grass-roots party organization to grasp poverty alleviation to promote the increase of peasants' income, and to explore and innovate boldly in the new rural construction. The development model of targeted poverty alleviation of "village-enterprise cooperation" under the guidance of the party organization has achieved good results and brought some new enlightenment to the reform and development of the rural areas. [3]

\section{PRACTICES AND Results OF "PARTY BuILDING +" INNOVATING POVERTY ALLEVIATION MODEL}

\section{A. "Kill Two Birds with One Stone"-Poverty Relief and Prompting Ambition Advance Shoulder to Shoulder}

"One leading geese, and two sets of groups." First of all, the successful entrepreneurs who start up business in other places take the lead to act as the village secretary, and play the role of leading geese by setting up a platform and establishing Wenzhou Ruixue Agricultural Development Co. Ltd. (hereinafter referred to as Ruixue Company). The village secretary launched more than 10 Thai businesses in other places to become a shareholder with more than 300 million yuan in advance, which solves the capital shortage of Ruixue Company. Secondly, the party members and backbone in the village set up a business team to do a good job in planning and publicizing policies. On the premise of ensuring collective ownership of rural land, the basic status of family management, and the existing land contract relationship remain unchanged, the villagers will be encouraged to put idle land into the stock and form a joint force. Thirdly, on the basis of setting up a platform, doing a good job in publicizing work and setting up a standing book, the village collective and all the villagers converted the land management right into the equity capital of about 1.6 million yuan, and each person becomes a shareholder by investing from 1,000 yuan to 30,000 yuan, accounting for $49 \%$ of the total share capital. In this way, the villagers will be guided to become a shareholder with the land, all the villagers participate in the joint operation and benefit from it together. More than $7000 \mathrm{mu}$ of land in the village has been transferred to the company, more than 220 villagers in the village became shareholders of the company, and basically realize the "covering the land and covering the villagers." 
Finally, it learns from the development experience of Huaxi Village to adopt the village-enterprise co-construction mode of "one-separation-multi-unity" to carry out the joint development: That is to say, on the basis of sticking to the separation of village and enterprise, modern enterprise management system is introduced to carry out unified planning, unified production, unified sales, and unified management, and the main cadres of the village party branch, village committee, village economic cooperative, and village supervision committee and so on respectively serve as directors or vice-directors of the company. Therefore, farmers' professional cooperatives, village funds mutual aid association and Ruixue company integrate together to form the mutual integration, mutual promotion, and mutual supervision between two groups of village and company. At present, the vanguard composed by party members as the backbone of the company constantly plays the role of a fighting fortress.

\section{B. "Three-Fold and Four-Digit"_ Work along both Lines of Blood Transfusion and Hematopoiesis}

The "triple guarantee" system constructs a long-term mechanism to increase farmers' income. Ruixue company is established to lead the economically weak villages to win the fight against poverty, which makes it clear at its establishment that Thai business do not participate in dividends at earlier stage, and gives the villagers unilateral unique dividend. The first is the share capital. Village collective and villagers with land as the stock can get dividend benefits in accordance with the shares. The second is the rent; fixed rent returns of 00-500 yuan/year mu are given respectively base on the term of land transfer. The tenancy term of hillwood is 30 years, and that of field is 15 years. The price of hillwood in the first six years is calculated according to the price of $33 \mathrm{jin} / \mathrm{mu}$ of paddy each year, and it doubles after six years; a rent of 300 yuan/mu is paid to the field in the first six years, and after six years it is paid at an annual rent of 500 yuan/mu, and the villagers themselves can choose to withdraw cash or recharge it into the share capital. The third is the salary. The local peasants and skilled workers who participate in the production of the company can get the remuneration of 100-140 yuan / day separately. The monthly salary reaches a total of 2500-4000 yuan, which is equivalent to that of migrant workers. Up to now, the company has issued a total salary of more than 500 million. The peasants can get paid every month and have dividends at the end of year. The poverty relief as blood transfusion and hematopoiesis helped peasants eat the "reassurance pill" and really saw the hope of getting rich.

The new cooperation model of "four in one" has taken initial effect. In particular, the strengthening of party construction has provided them with standardized systems, personnel support and technical support, improved the contradictions in cooperation, and made the cooperation more systematic and humanized, which can effectively improve the efficiency of resource use and benefit of agricultural production. It achieves the virtuous cycle model of Thai businessmen, companies, collectives, farmers "four in one" where Thai companies benefit, the company flourish, the income of village collective doubled and peasants get rid of poverty. It is specifically reflected as: first is the vanguard role of "party construction + ". The village party branch takes the lead to encourage the farmers to take the land as the stock, revitalizes the sleeping land capital, and safeguards their benefit in the distribution of land increment income. It leads the village collective to achieve common prosperity, avoiding the problems of polarization between rich and poor, unequal distribution and social injustice, as well as the social contradictions of power imbalance and moral hazard, and promote the current operation mechanism of "one separation and multi-unity, self-building and self-operating" in the village, which greatly enhances the cohesion of the party and the masses, effectively prevent corruption in the rural areas, and finally realize the typical successful case of the village becoming co-rich. Second is the organizational guarantee function of "party construction +". As the organizer and escort of the farmers' land equity, the Party organization, in the course of guaranteeing the market economy and the rural reform, consider more about the farmers' vital interests, avoids the rights and interests enjoyed by the farmers being occupied by a few people, and makes the value-added of the land enjoyed by the farmers and the profits of the company be extended and protected for a long time. Third is the promotion role of "party construction + ". The innovation practice of the operation mode and the development of company not only have the routine management mode, but also achieve the innovation development in the system, the person management and the safeguard measure under the guidance of red cell, which promotes the real combination between land and the capital. It is the land management innovation at a higher level to change the weak position of scattered management in the market. Fourth is the role of platform building of "party construction + ". Efforts should be made to build a platform for equal exchange of social capital elements and condense the factors of production, thus realizing the enthusiasm for investment of foreign Thai merchants and the transformation from external "blood transfusion" in the past to self-management "hematopoiesis", to achieve the transformation and upgrading of funds from public welfare undertakings to production development, and truly realize the "multiplier effect" of farmers' income. At the same time, we should promote farmers to participate in the company's construction projects with a higher enthusiasm, and build a good development platform where party leads the enterprises, village protects the enterprises, and village and enterprise cooperate with each other, mutually integrates, and promote each other.

\section{The Party Construction Has Achieved Results and \\ Poverty Alleviation Promotes Party Construction}

There are 222 households in Xue Ne Village with 823 people. In 2010, the average net income of the villagers was 5730 yuan. Among them, there were 60 households with 198 people are low-income households, so it is one of the key poor villages in Taishun. Through only three years of development, the result is remarkable. First, the company's assets have been increased from more than 12 million yuan to more than 45 million yuan, and the per capita income of farmers in the village has been increased to 12,600 yuan, 
doubling in past three years, which exceeds by 37 percent of the per capita income of 9158 yuan for farmers in the county. It not only solved the employment of more than 300 people in the village, but also began to radiate the farmers in surrounding village, and produced good economic and social benefits. Second, a modern agricultural park that combines science and technology demonstration, sightseeing and picking, and leisure and holiday has begun to take shape, and takes the road of benefit, ecologicalized and technicalized agriculture, to expand the production scale in an all-round way and speed up the promotion of production efficiency. At present, the company has oil-tea base $3350 \mathrm{mu}$, tea base 200 $\mathrm{mu}$, bayberry base $300 \mathrm{mu}$, and kiwi fruit base $450 \mathrm{mu}$. At present, there are one tea processing factory, one oil tea processing factory and its matched refrigeratory, and the company registered its own "Ruixuebao" trademark. With the help of the resources advantages and market advantages of the outside Thai merchants, at present, kiwi fruit, oil tea and tea products are exported to Shanghai, Shandong, Hangzhou and other provinces and cities through local Wenzhou merchants chambers of commerce, entity monopoly and e-commerce platform. Third, party construction is promoted mutually, and the consciousness of serving the people has been further strengthened. The construction of party branch has changed the original weak and lax condition, and is gradually creating the brand party branch and the service party branch, so the function of battle fortress is further strengthened, making it win one gold metal, three silver metal and one copper metal in "the five stars striving", and is appraised by the county party committee as "the outstanding party branch". At the same time, there are also charitable special funds set in the company and the party branch for the elderly condolence, medical aid, and education awards and other public welfare undertakings. They do their best to benefit the whole village, and further enhance the relationship between the party and the masses.

\section{ENLIGHTENMENT AND REFLECTIONS}

\section{A. To Choose the "Red Leading Geese" and Make Good Use of the Leaders at the Village Level}

We should take strengthening the leadership of the party, promoting the grass-roots governance system and targeted poverty alleviation as the goal, grasp the "red position" and "red cell" to choose and make good use of village-level leader. According to the requirement of starting an enterprise with idea, serving the masses with emotion, leading the team with methods, willing to devote one and bearing hardships, we should deeply carry out the selecting work of excellent village secretaries. In particular, we need to attract the party members with high prestige and dedication in the village to join the leadership core in the village to lead the scientific management of party members and stimulate positive energy of targeted poverty alleviation. To solve the problem of "who comes to help", the key is to select the party member vanguard who "remembers nostalgia" to help the collective construction of the village, so that we can really see the actual effect in the precise landing.

\section{B. To Build Information Platform with "Red Homesickness"}

To implement targeted poverty alleviation, the potential and momentum lie in the large collection of social forces. First, we can expand channels, raise funds, make good use of entrepreneurs outside the village and set up a good information platform to implement the profound feelings of thinking of the source when becoming rich and back to support the hometown in specific actions, and give preference in policy and technical assistance. This will certainly attract more entrepreneurs and social forces to participate in the construction of their hometown. Second, we should stimulate their entrepreneurial enthusiasm back home, and actively encourage the outside talent to return to hometown. We should give full play to the role of local experts, entrepreneurs, and technical personnel to return home to help hometown construction, making them the "main force" in restructuring rural entrepreneurship and promoting practical technologies. Third, the safeguards should be in place and a coordination mechanism is set up to build a more effective and direct platform for the vast number of outside Thai merchants to nurture agriculture by industry and return the hometown. We can also advocate all social forces to participate in targeted poverty alleviation, and build a large poverty alleviation pattern combining point, line and area so that the rich first push on those being rich later and make the "red nostalgia" an important cornerstone for the smooth progress of poverty alleviation.

\section{To Promote the "Party Construction + "Poverty Alleviation Model to Enhance the Role of Battle Fortress}

We should carry out the "party construction +" work mode, guide targeted poverty alleviation into party construction work, give full play to the advantages of activities such as "five-star striving" "index of party member vanguard" and "red cell project," and gradually establish a new system of network party construction with red cells, red positions, and targeted poverty alleviation. We should accelerate the main party construction work of targeted poverty alleviation under the new situation. We should strengthen the work responsibilities of the "First Secretary", practice drop irrigation techniques for targeted poverty alleviation, and practically shoulder the new mission of "working in a real place with no limits and walking in the front row to seek a new chapter" to guide grass-roots party organizations to strive for excellence, and make efforts to form a batch of demonstration groups of grass-roots party organizations and vanguard groups of party members.

\section{Innovating the Reform to Stimulate the Vitality of Resources}

The third, the fourth and fifth plenary sessions of the 18th Central Committee of the Communist Party of China sounded the bugle of a new round of reform. With the deepening of the reform of the rural property right system, the reform with the transfer system of the contracted management right of rural land, the property right system of rural collective assets, and the grass-roots management system of township (town) village as the main content has been continuously innovated and perfected. In targeted 
poverty alleviation, we should seize the achievements of the rural reform pilot area, make bold attempts and break the shackles of institutional mechanisms to achieve the purpose of capital and resources transforming from "co-construction" to "win-win. We should encourage and support the return of the Wenzhou businessmen outside the city, and attract central enterprises and multinational companies to invest in the construction of mountainous areas. We can vigorously promote the development and utilization of mild slope of low hill, scientifically and rationally develop the resource of mild slope of low hill, develop characteristic industry of mountain area according to local conditions, and build a batch of model village of profitable agriculture and characteristic industry village to revitalize the sleeping "land capital". We also encourage the innovation of the agricultural operation mode, such as household management, collective management, cooperative management and enterprise management, and accelerate the construction of a new type of agricultural management system.

\section{CONCLUSION}

Although the village-enterprise cooperation model under "party construction +" has achieved some results with a strong demonstration role and practical feasibility, and provides a new realization approach for the targeted poverty alleviation in new situation, some real problems such as poor awareness of peasant, limited ability to accept new things and new models, and single workforce also constrain development. Therefore, it is necessary to increase publicity, scientific guidance, and praise typical example and create model. We should give more policy support and financial support to the village-enterprise cooperation, subsidize and reward the introduction and promotion of new varieties and new technologies, vocational training for farmers, and the construction of infrastructure in the village.

\section{REFERENCES}

[1] Communique on the Fifth Plenary Session of the 18th Central Committee of the Communist Party of China [J]. Party Building, 2015, (11): 25-27.

[2] The Xinhua News Agency. Central Poverty Alleviation and Development Conference is held [J]. China Poverty Alleviation, 2015, (23): 4-7.

[3] Lin Quan, Lu Xiaoping, Pan Bo. "Ruixue model" - exploration and research of poverty alleviation by combining village and enterprise [J] .New countryside, 2015,10: 13-14. 